\title{
Assessment of Heritable Variation and Best Combining Genotypes for Grain Yield and Its Attributes in Bread Wheat
}

\author{
Nusrat Parveen ${ }^{*}$, Amna Kanwal2, Etlas Amin'1, Fariha Shahzadi' ${ }^{3}$, Saba Aleem¹, Mehvish Tahir ${ }^{1}$, \\ Abia Younas4, Rasheda Aslam1, Nafeesa Aslam', Iqra Ghafoor ${ }^{2}$, Mehvish Makhdoom², \\ Muhammad Amin Shakir', Muhammad Najeebullah'
}

\author{
${ }^{1}$ Vegetable Research Institute, AARI, Faisalabad, Pakistan \\ ${ }^{2}$ Wheat Research Institute, AARI, Faisalabad, Pakistan \\ ${ }^{3}$ Rice Research Institute, Kala Shah Kako, Pakistan \\ ${ }^{4}$ Cotton Research Station, AARI, Faisalabad, Pakistan \\ ${ }^{5}$ Department of Plant breeding and Genetics, University of Agriculture, Faisalabad, Pakistan \\ ${ }^{6}$ Livestock Production Research Institute, Bahadernagar Farm, Okara, Pakistan \\ Email: nusratvri@gmail.com
}

How to cite this paper: Parveen, N., Kanwal, A., Amin, E., Shahzadi, F., Aleem, S., Tahir, M., Younas, A., Aslam, R., Aslam, N., Ghafoor, I., Makhdoom, M., Shakir, M.A. and Najeebullah, M. (2018) Assessment of Heritable Variation and Best Combining Genotypes for Grain Yield and Its Attributes in Bread Wheat. American Journal of Plant Sciences, 9, 1688-1698. https://doi.org/10.4236/ajps.2018.98122

Received: June 6, 2018

Accepted: July 21, 2018

Published: July 24, 2018

Copyright ( 92018 by authors and Scientific Research Publishing Inc. This work is licensed under the Creative Commons Attribution International License (CC BY 4.0).

http://creativecommons.org/licenses/by/4.0/

(c) (i) Open Access

\begin{abstract}
Grain yield in wheat is the resultant of several plant attributes. It is very important to assess heritable variation involved in the inheritance of these attributes in addition to find the best combining genotypes. For this purpose, the present study involving $5 \times 5$ full diallel analysis was performed. Twenty $\mathrm{F}_{1}$ hybrids along with their parents $(9797,9801,9802$, Chakwal-50 and Chakwal-86) were planted in field using randomized complete block design (RCBD) with three replications in the research area of Department of Plant Breeding and Genetics, University of Agriculture, Faisalabad during 2015-2016. Plant characters like plant height, flag leaf area, spike length, No. of fertile tillers per plant, No. of grains per spike, No. of spikelets per spike, 1000 grain weight and grain yield per plant were studied in this experiment. Mean squares due to general combining ability (GCA) were highly significant for all the traits except for spike length for which GCA effects were significant. Mean squares due to specific combining ability (SCA) and reciprocal combining ability (RCA) were highly significant for all the characters studied. GCA variance was higher than the SCA variance for spike length and No. of grains per spike exhibiting the predominant role of additive genetic variation in the inheritance of these traits. However, for the characters like plant height, flag leaf area, No. of fertile tillers per plant, No. of spikelets per spike, 1000 grain weight and grain yield per plant, the value of SCA variance was higher than the value of GCA variance showing non additive gene action for these
\end{abstract}


traits. The variety Chakwal-50 proved to be the best general combiner for plant height, spike length, No. of spikelets per spike, No. of grains per spike and grain yield per plant. The cross, $9802 \times$ Chakwal- 86 was the best specific combination for grain yield and most of the yield attributes. The good general and specific combiners are important breeding resources for the initiation of future wheat breeding programmes aimed at enhancement of grain yield in bread wheat.

\section{Keywords}

Wheat, Combining Ability, Yield, Diallel, Additive Genetic Variation

\section{Introduction}

Wheat (Triticum aestivum L.) is a cereal crop originated in Middle East. It is a self pollinated crop belonging to Poaceae family. Bread wheat is hexaploid species and has three genomes namely A, B and D [1]. Genetic study of wheat is complex because of its large genome size. Wheat supply $20 \%$ of total calories consumed by human daily. The genetic studies of wheat enabled breeders to develop high yielding, good quality and disease resistant varieties. It has vital position in Pakistan agricultural policies and in international trade wheat share is more than other crops combined. Contribution of wheat to GDP is $1.9 \%$ and 9.6\% to value added in agriculture. During 2016-2017, it was cultivated on 9052 thousand hectares and total production was 25.75 million tonnes and yield was $2752 \mathrm{~kg} / \mathrm{ha}$ [2]. Grain is a good source of carbohydrates, vitamins and minerals. Amount of protein in wheat is more than other cereals and thus a main source of vegetable protein worldwide. Consumption of wheat is increasing by $2 \%$ worldwide per year, to fill this increasing demand there is a need to develop high yielding and disease resistant varieties. Genetic studies of wheat provided the information useful in developing wheat varieties with high yield and improved quality [3].

Combining ability studies invented by [4] depict the ability of the parents to transmit their useful characters to next generation and assess the performance of genotypes in cross combinations [5]. Diallel analysis gives information about the inheritance and gene action that enables the plant breeder to do selection in earlier or later generations. Mean performance of a line in cross combinations is evaluated by general combining ability (GCA) and GCA is linked to the percentage of additive type of gene action [6]. SCA is the estimation of the performance of progeny derived from a specific cross in relation to what would be expected based on the average performance of the genotypes involved.

Keeping in view of the above situation the research study was carried out with the following objectives;

1) To assess performance of five bread wheat genotypes and their $F_{1} s$ to recognize the best performing genotypes, 
2) To study the GCA and SCA to discover the best general combiners and hybrid combinations for yield and its related components.

\section{Materials and Methods}

The present research to estimate the combining ability effects for wheat yield and its related traits was carried out in the experimental area of Department of Plant Breeding and Genetics, University of Agriculture Faisalabad (UAF) during 2014-2016. The experimental material was comprised of five different lines/varieties of spring wheat, namely 9797, 9801, 9802, Chakwal-50 and Chakwal-86. During 2014-2015 the genotypes were planted and crossed in all possible combinations according to full diallel crossing scheme. Prior to anthesis the florets on a spike of the female parents were emasculated by clipping back the glumes and removing anthers with fine pointed tweezers. To avoid self-pollination any flower with mature anthers was excluded. The emasculated spikes were enclosed separately in butter paper bags. A day after emasculation pollinations were made by shaking ripe anthers from the male parent plant on to the mature stigma. The spikes, in which crosses were made, were covered again with butter paper bags for about one week to prevent any other cross fertilization. At maturity the crossed seed was harvested from each female parent and parental lines. Seeds of twenty $F_{1}$ crosses along with their parents were sown in the experimental area on November 22, 2015 in a triplicate randomized complete block design. The entries were assigned at random to experimental units in each block. The interplant and inter row distances were $15 \mathrm{~cm}$ and $30 \mathrm{~cm}$, respectively. Two seeds per hole were sown with the help of dibbler and after germination thinning was done to have a single healthy seedling per hole. Standard cultural practices, irrigation, fertilizer and hoeing were provided to all treatments.

At maturity, 10 guarded plants were selected randomly from each row of each replication and data were recorded for traits like plant height, flag leaf area, spike length, No. of fertile tillers per plant, No. of grains per spike, No. of spikelets per spike, 1000 grain weight and grain yield per plant. Analysis of variance for combining ability was carried using Griffing approach [4] (Method I Model II). Estimates of GCA, SCA and reciprocal effects and their variances were also calculated by Griffing approach [4].

\section{Results and Discussion}

The results pertaining to the heritable variation and inheritance pattern of grain yield and its various attributes are given below.

\subsection{Plant Height}

In wheat negative combining ability effects are desirable for plant height. Analysis of variance for combining ability revealed that mean squares for GCA, SCA, and RCA effects were highly significant (Table 1). Although mean squares of 
Table 1. Analysis of variance for combining ability in a $5 \times 5$ diallel cross of whea.

\begin{tabular}{cccccccccc}
\hline SOV & D.F & $\begin{array}{c}\text { Plant } \\
\text { height }\end{array}$ & $\begin{array}{c}\text { Flag leaf } \\
\text { area }\end{array}$ & $\begin{array}{c}\text { Spike } \\
\text { length }\end{array}$ & $\begin{array}{c}\text { Fertile } \\
\text { tillers per } \\
\text { plant }\end{array}$ & $\begin{array}{c}\text { Grains } \\
\text { per } \\
\text { spike }\end{array}$ & $\begin{array}{c}\text { Spikelets } \\
\text { per spike }\end{array}$ & $\begin{array}{c}1000 \\
\text { grain } \\
\text { weight }\end{array}$ & $\begin{array}{c}\text { Grain } \\
\text { per } \\
\text { plant }\end{array}$ \\
\hline GCA & 4 & $46.82^{* *}$ & $22.26^{* *}$ & $1.76^{*}$ & $5.91^{* *}$ & $50.74^{* *}$ & $2.27^{* *}$ & $9.24^{* *}$ & $4.64^{* *}$ \\
SCA & 10 & $28.55^{* *}$ & $23.86^{* *}$ & $1.51^{* *}$ & $2.91^{* *}$ & $51.94^{* *}$ & $4.23^{* *}$ & $15.79^{* *}$ & $9.33^{* *}$ \\
RCA & 10 & $58.55^{* *}$ & $5.59^{* *}$ & $1.85^{* *}$ & $4.82^{* *}$ & $82.38^{* *}$ & $2.83^{* *}$ & $12.84^{* *}$ & $7.94^{* *}$ \\
Error & 48 & 8.83 & 1.57 & 0.49 & 0.43 & 0.81 & 0.59 & 0.82 & 4.11 \\
\hline
\end{tabular}

* = Significant at $\mathrm{P} \leq 0.05 ;{ }^{* *}=$ Highly Significant at $\mathrm{P} \leq 0.01$.

GCA (46.82) were greater than SCA mean squares (28.55) but estimates of components of variance (Table 2) showed that SCA variance (11.74) was greater than GCA variance (1.92) which displayed that non-additive genetics effects were involved in controlling this trait. These results are in agreements with findings of [7] [8] [9] [10] that the plant height is controlled by non-additive type of genetic mechanism.

The estimates of GCA effects of parents were in the range of -2.21 to 2.95 for the plant height (Table 3). The highest positive GCA effects were exhibited by the parent 9797 with the value of 2.95 and the highest negative effects for this trait were depicted by parent Chakwal-50 having the value of -2.21 followed by 9802 (-2.04). The negative GCA values are preferred for introducing dwarfing genes in high yielding varieties. SCA effects are shown in Table 4 . The cross namely $9801 \times 9802$ had the highest positive SCA value (4.33) followed by 9802 $\times$ Chakwal-50 (3.52). Cross, Chakwal-50 $\times$ Chakwal-86 (-5.75) exhibited the highest negative SCA effects followed by $9797 \times 9801(-3.86)$ exhibiting that the hybrids of these crosses will give more desirable segregates and will be helpful in hybrid wheat development programmes. The lowest reciprocal effects for plant height were exhibited by Chakwal-50 × 9797 (-9.76) followed by Chakwal-86 $\times$ 9802 (-6.35). The highest positive reciprocal effects were depicted by Chakwal-86 $\times 9797$ (8.96) followed by Chakwal-86 $\times 9801$ (6.89) $($ Table 5).

\subsection{Flag Leaf Area}

Combining ability analysis showed that mean squares due to GCA, SCA and RCA effects were highly significant for flag leaf area (Table 1). Mean square values for SCA were greater than GCA mean squares. Similarly variance of SCA

Table 2. Estimation of components of variation for combining abilities of some polygenic traits in a $5 \times 5$ diallel crosses of wheat.

\begin{tabular}{ccccccccc}
\hline $\begin{array}{c}\text { Components } \\
\text { of variation }\end{array}$ & Plant height & $\begin{array}{c}\text { Flag leaf } \\
\text { area }\end{array}$ & Spike length & $\begin{array}{c}\text { Fertile tillers per } \\
\text { plant }\end{array}$ & $\begin{array}{c}\text { Grains per } \\
\text { spike }\end{array}$ & $\begin{array}{c}\text { Spikelets per } \\
\text { spike }\end{array}$ & $\begin{array}{c}1000 \text { grain } \\
\text { weight }\end{array}$ & $\begin{array}{c}\text { Grain yield } \\
\text { per plant }\end{array}$ \\
\hline Vg & 1.92 & -5.35 & 0.61 & 0.31 & 30.43 & -0.18 & -0.58 & -0.43 \\
Vs & 11.74 & 13.26 & 0.02 & 1.48 & 0.12 & 2.17 & 8.91 & 5.31 \\
Vr & 24.86 & 2.00 & 0.68 & 2.19 & 40.78 & 1.12 & 6.01 & 3.76 \\
\hline
\end{tabular}


N. Parveen et al.

Table 3. Estimates of general combining ability effects for some polygenic traits of wheat in a $5 \times 5$ diallel cross of wheat.

\begin{tabular}{cccccccccc}
\hline Parents & Plant height & $\begin{array}{c}\text { Flag leaf } \\
\text { area }\end{array}$ & Spike length & $\begin{array}{c}\text { Fertile tillers } \\
\text { per plant }\end{array}$ & $\begin{array}{c}\text { Grains per } \\
\text { spike }\end{array}$ & $\begin{array}{c}\text { Spikelets per } \\
\text { spike }\end{array}$ & $\begin{array}{c}\text { 1000 grain } \\
\text { weight }\end{array}$ & $\begin{array}{c}\text { Grain yield per } \\
\text { plant }\end{array}$ \\
\hline $\mathbf{9 7 9 7}$ & 2.95 & 1.13 & 0.31 & 0.88 & -1.03 & -0.66 & 0.40 & 0.94 \\
$\mathbf{9 8 0 1}$ & 0.43 & -1.02 & -0.07 & -0.89 & -2.22 & 0.14 & -0.49 & 0.11 \\
$\mathbf{9 8 0 2}$ & -2.04 & -0.98 & -0.67 & 0.01 & 2.35 & 0.31 & 1.15 & -0.98 \\
Chakwal-50 & -2.21 & -1.19 & 0.32 & 0.63 & 2.50 & 0.51 & -0.63 & 1.23 \\
Chakwal-86 & 0.86 & 2.05 & 0.14 & -0.63 & -1.59 & -0.29 & -0.79 & 0.04 \\
\hline
\end{tabular}

Table 4. Estimates of specific combining ability effects for some yield and yield related traits in a $5 \times 5$ full diallel cross of wheat.

\begin{tabular}{ccccccccc}
\hline Crosses & $\begin{array}{c}\text { Plant } \\
\text { height }\end{array}$ & $\begin{array}{c}\text { Flag leaf } \\
\text { area }\end{array}$ & Spike length & $\begin{array}{c}\text { Fertile tillers } \\
\text { per plant }\end{array}$ & $\begin{array}{c}\text { Grains per } \\
\text { spike }\end{array}$ & $\begin{array}{c}\text { Spikelets per } \\
\text { spike }\end{array}$ & $\begin{array}{c}\text { 1000 grain } \\
\text { weight }\end{array}$ & $\begin{array}{c}\text { Grain yield } \\
\text { per plant }\end{array}$ \\
\hline $\mathbf{9 7 9 7} \times \mathbf{9 8 0 1}$ & -3.86 & 2.81 & 0.46 & 0.52 & 3.18 & 1.57 & -1.03 & -1.90 \\
$\mathbf{9 7 9 7} \times \mathbf{9 8 0 2}$ & -0.92 & -2.21 & -0.78 & -1.44 & 0.48 & -2.27 & -0.98 & 2.18 \\
$\mathbf{9 7 9 7} \times$ Chakwal-50 & 2.29 & -0.86 & -0.75 & -0.41 & -4.41 & 0.05 & -0.22 & -1.20 \\
$\mathbf{9 7 9 7} \times$ Chakwal-86 & 1.73 & 1.88 & -0.09 & 0.98 & -2.45 & 0.19 & 0.41 & -2.60 \\
$\mathbf{9 8 0 1} \times \mathbf{9 8 0 2}$ & 4.33 & 1.35 & -1.25 & -1.49 & -1.00 & -0.11 & 1.78 & -0.96 \\
$\mathbf{9 8 0 1} \times$ Chakwal-50 & 1.98 & 2.74 & 0.29 & -0.54 & 0.08 & 1.76 & 1.27 & 1.18 \\
$\mathbf{9 8 0 1} \times$ Chakwal-86 & -1.98 & -2.59 & 0.64 & 1.16 & 8.20 & -0.05 & -4.73 & 1.16 \\
$\mathbf{9 8 0 2} \times$ Chakwal-50 & 3.52 & -4.74 & 0.13 & 1.00 & -2.76 & -1.36 & 2.52 & 1.98 \\
$\mathbf{9 8 0 2} \times$ Chakwal-86 & -1.98 & 0.26 & 1.2 & 1.55 & 8.43 & 1.45 & 3.33 & 2.48 \\
Chakwal-50 $\times$ Chakwal-86 & -5.75 & 4.66 & 0.07 & -1.28 & 5.32 & -2.11 & -0.64 & -0.10 \\
\hline
\end{tabular}

Table 5. Estimates of reciprocal effects for some yield and yield related traits in a $5 \times 5$ full diallel cross of wheat.

\begin{tabular}{|c|c|c|c|c|c|c|c|c|}
\hline Crosses & $\begin{array}{l}\text { Plant } \\
\text { height }\end{array}$ & $\begin{array}{c}\text { Flag leaf } \\
\text { area }\end{array}$ & $\begin{array}{l}\text { Spike } \\
\text { length }\end{array}$ & $\begin{array}{c}\text { Fertile tillers } \\
\text { per plant }\end{array}$ & $\begin{array}{l}\text { Grains per } \\
\text { spike }\end{array}$ & $\begin{array}{l}\text { Spikelets per } \\
\text { spike }\end{array}$ & $\begin{array}{c}1000 \text { grain } \\
\text { weight }\end{array}$ & $\begin{array}{c}\text { Grain yield } \\
\text { per plant }\end{array}$ \\
\hline $9801 \times 9797$ & 2.41 & -0.73 & 0.35 & -1.66 & -3.63 & -1.44 & -0.51 & -1.58 \\
\hline $9802 \times 9797$ & -0.84 & 2.69 & -0.73 & -2.33 & -12.67 & 1.53 & -3.46 & 2.22 \\
\hline $9802 \times 9801$ & 1.29 & -2.08 & -0.36 & -1.62 & -1.01 & -1.77 & -0.09 & -0.43 \\
\hline Chakwal-50 × 9797 & -9.75 & -1.51 & -0.93 & 1.69 & -0.38 & -0.37 & 1.61 & -4.06 \\
\hline Chakwal-50 × 9801 & 3.96 & 1.11 & -0.27 & 2.43 & 2.33 & -1.58 & 3.91 & 1.86 \\
\hline Chakwal-50 × 9802 & -1.09 & -1.41 & 0.08 & 0.84 & -12.58 & 0.23 & 1.88 & 0.35 \\
\hline Chakwal-86 × 9797 & 8.96 & -1.02 & 2.12 & -0.76 & 6.68 & -1.66 & 4.88 & 2.13 \\
\hline Chakwal-86 × 9801 & 6.89 & -0.10 & 1.34 & 1.25 & -5.04 & -0.02 & -1.78 & 0.16 \\
\hline Chakwal-86 × 9802 & -6.36 & 3.03 & -0.99 & 0.58 & -1.45 & -1.08 & 0.51 & -1.81 \\
\hline Chakwal-86 $\times$ Chakwal-50 & -2.03 & -0.07 & 0.40 & -1.13 & -0.97 & 0.01 & 1.79 & 2.02 \\
\hline
\end{tabular}

effects (Table 2) was greater than variance of GCA effects indicating the predominance of nonadditive gene action. The above results are in agreement with the findings of [11] [12] [13] who reported nonadditive gene action for flag leaf area. However, [7] [14] reported additive gene action for governing flag leaf area. 
The estimates of GCA (Table 3) revealed that parent Chakwal-86 (2.05) exhibited the highest positive GCA effects for flag leaf area followed by 9797 (1.13) remaining three parents had negative GCA effects. Chakwal-50 was the poorest general combiner with highest negative GCA effects (-1.19). The cross namely Chakwal-50 $\times$ Chakwal-86 exhibited the highest positive SCA effects (Table 4) which were 4.66 followed by $9797 \times 9801(2.80)$ while the cross $9801 \times$ Chakwal-50 showed the highest negative SCA effects which were -4.74 followed by $9801 \times$ Chakwal-86 (-2.59). Two crosses Chakwal-86 ×9802 and $9802 \times 9797$ manifested positive reciprocal effects of 3.03 and 2.69 respectively and remaining crosses manifested negative reciprocal effects ranging from $-2.08(9802 \times 9801)$ to -1.51 (Chakwal-50 $\times$ 9797) (Table 5). The above discussion revealed that the best general combiner for the flag leaf area was Chakwal-86 and the best specific combiner for this trait was Chakwal-50 $\times$ Chakwal-86.

\subsection{Spike Length}

ANOVA for combining ability depicted that the mean squares for general combining ability were significant. While the mean squares due to SCA effects and RCA effects were highly significant (Table 1). Mean squares of GCA (1.76) were higher than mean squares of SCA (1.51) indicating the importance of additive type of gene action for spike length and mean squares of RCA were 1.85. Calculation of variance components also confirmed additive type of gene action for spike length (Table 2). These results are in agreements with the findings of [9] [15].

Estimates of GCA effects are given in Table 3. Results revealed that the good general combiners for spike length were Chakwal-50 and 9797 with GCA effects of 0.32 and 0.31 respectively. Genotypes $9802(-0.67)$ and $9801(-0.07)$ exhibited the high negative GCA values thus proved poor combiners for spike length. Estimates for the SCA effects (Table 4) were studied and the value 1.20 was the highest positive value for this trait which was exhibited by the cross namely 9802 $\times$ Chakwal-86 followed by $9801 \times$ Chakwal-86 (0.64). Negative SCA effects of $-1.25,-0.78,-0.75$ and -0.09 were exhibited by the crosses namely, $9801 \times$ $9802,9797 \times 9802,9797 \times$ Chakwal-50 and $9797 \times$ Chakwal-86 respectively. Highest positive reciprocal effects were shown by cross Chakwal-86 $\times 9797$ with 2.12 value followed by Chakwal-86 $\times 9801$ (1.34) and highest negative reciprocal effects $(-0.99)$ were exhibited by a cross named as Chakwal-86 $\times 9802$ (Table 5).

\subsection{Fertile Tillers per Plant}

ANOVA for combining ability depicted the highly significant mean squares due to GCA (13.8), SCA (6.80) and RCA effects (4.82) (Table 1). Although the mean squares of GCA were higher than the mean squares of SCA for No. of tillers per plant but computation of variance components showed that SCA variance was higher than the variance of GCA denoting the non-additive gene action for fertile tillers per plant (Table 2). These results are in accordance with the results of [14] [16] [17]. The contrary results were reported by [18] [19]. 
For this trait the estimates GCA effects revealed that parent namely 9797 exhibited the highest positive GCA value which was 0.88 followed by Chakwal-50 (0.63) and the genotype 9801 exhibited the highest negative value -0.89 followed by Chakwal-86 (-0.63) (Table 3). Three crosses namely $9802 \times$ Chakwal-86, $9801 \times$ Chakwal-86 and $9802 \times$ Chakwal-50 were good specific combiners for fertile tillers per plant with the positive SCA effects (1.55, 1.16 and 1.00 respectively). Weakest specific combination for this trait was the hybrid $9801 \times 9802$ $(-1.49)$ followed by $9797 \times 9802(-1.44)$ (Table 4$)$. In case of reciprocal effects (Table 5) maximum value was shown by cross Chakwal-50 $\times 9801$ (2.43) followed by Chakwal-50 $\times 9797$ (1.69) and Chakwal-86 $\times 9801$ (1.25). The cross $9802 \times 9797$ exhibited poorest performance with highest negative reciprocal effects $(-2.33)$. Four other crosses namely $9801 \times 9797,9802 \times 9801$, Chakwal-86 $\times$ Chakwal-50 and Chakwal-86 $\times 9797$ also displayed negative reciprocal effects of $-1.66,1.62,-1.13$ and -0.76 respectively. Parent, 9797 was the best general combiner and cross $9802 \times$ Chakwal-86 was the best specific combination for fertile tillers per plant.

\subsection{No. of Grains per Spike}

Analysis of variance for combining ability showed that there were highly significant means squares for GCA, SCA and RCA (Table 1). These results exhibited that the mean square value for GCA ruled over SCA mean square indicating predominant additive type of gene action for this trait. Higher GCA variance than variance of SCA also confirmed the presence additive genetic effects (Table 2). The similar findings, which indicated additive type of gene action, were obtained by [9] [20].

Estimates of general combining ability effects (Table 3 ) revealed that parent Chakwal-50 (2.49) possessed highest positive GCA effects followed by 9802 (2.35) and highest negative value was -2.21 possessed by genotype 9801 followed by -1.59 (Chakwal-86). Estimates for the SCA effects (Table 4) depicted that crosses $9802 \times$ Chakwal-86 and $9801 \times$ Chakwal-86 showed excellent performance for grains per spike with high positive SCA effects (8.43 and 8.20 respectively) followed by Chakwal-50 $\times$ Chakwal-86 (5.32). The highest negative value was shown by $9797 \times$ Chakwal-50 (-4.41) thus it was the weakest specific combiner. Three other crosses also displayed negative SCA effects of $-2.76(9802 \times$ Chakwal-50), $-2.45(9797 \times$ Chakwal-86) and $-1.00(9801 \times 9802)$. Highest positive reciprocal combining ability effects were shown by cross Chakwal-86 $\times$ 9797 (6.67) followed by Chakwal-50 × 9797 (2.33) and high negative reciprocal effects of -12.67 and -12.58 were exhibited by crosses named as $9802 \times 9797$ and Chakwal-50 $\times 9802$ respectively (Table 5). Parent, Chakwal-50 proved to be best general combiner and cross, namely $9802 \times$ Chakwal- 86 was the best specific combination for No. of grains/spike.

\subsection{No. of Spikelets per Spike}

The analysis of variance for combining ability revealed that mean squares due to 
GCA (2.26), SCA (4.23) and RCA (2.83) were highly significant. Mean squares due to SCA (4.23) were greater than GCA mean squares (2.26) and reciprocal combining ability (2.83) mean squares (Table 1 ). Similarly estimates of variance components depicted that SCA variance was higher than GCA variance (Table 2 ). Thus indicating predominant role of non additive gene action for No. of spikelets/spike. These results are in agreement with the findings of [10] [21] [22]. The different results which showed additive gene action for spikelets/spike were reported by [20] [23].

Estimates of GCA effects (Table 3) revealed that three parents namely Chakwal-50, 9802 and 9801 exhibited the positive GCA effects of $0.51,0.31$ and 0.14 respectively. Chakwal-50 proved to be the good general combiner as it exhibited the highest value for GCA effects. The highest negative GCA effects were possessed by $9797(-0.66)$ followed by Chakwal-86 $(-0.29)$. The maximum SCA effects were exhibited by the cross $9801 \times$ Chakwal-50 (1.76) followed by $9797 \times$ 9801 (1.57) and $9802 \times$ Chakwal-86 (1.45) for this character. Thus cross $9802 \times$ Chakwal-50 was the best specific combination (Table 4). Two crosses $9797 \times$ 9802 and Chakwal-50 $\times$ Chakwal-86 were poor specific combiners for spikelets/spike possessing high negative SCA effects of -2.27 and -2.11 respectively. For the reciprocal combining ability the cross $9802 \times 9797$ (1.53) has the maximum positive value and cross $9802 \times 9801(-1.77)$ has highest negative value (Table 5).

\subsubsection{Grain Weight}

ANOVA for combing ability revealed that mean squares due to GCA (9.23), SCA (15.79) and RCA (12.84) effects were highly significant for 1000 grain weight (Table 1). The mean squares due to SCA were greater than GCA mean squares. Thus, indicated the presence of non additive type of gene action. For 1000 grain weight the estimates of genetic components of variance due to general, specific and reciprocal combining ability were studied and the estimates were $-0.58(\mathrm{Vg}), 8.91(\mathrm{Vs})$ and $6.01(\mathrm{Vr})$ as given in Table 2. Computation of variance components also exhibited the pronounced role of non additive gene action in controlling the inheritance of 1000 grain weight. The similar conclusion that indicated non additive effects were obtained by [9] [24].

The genotype, 9802 exhibited the maximum positive GCA effects with 1.51 value followed by $9797(0.40)$ and highest negative GCA effects were exhibited by Chakwal-86 (-0.79) pursued by Chakwal-50 (-0.63) (Table 3). Estimates of SCA effects showed that the cross $9802 \times$ Chakwal-86 exhibited the highest positive SCA effects with the value of 3.33 and cross $9801 \times$ Chakwal-86 showed the maximum negative value which was -4.74 (Table 4 ). The highest positive reciprocal effects were depicted by the cross Chakwal-86 $\times 9797$ (4.88) while highest negative reciprocal effects $(-3.46)$ were displayed by $9802 \times 9797$ (Table 5).

\subsection{Grain Yield per Plant}

ANOVA for combining ability (Table 1) exhibited highly significant mean 
squares due to GCA (4.64), SCA (9.33) and RCA (7.94). The mean squares due to SCA were greater than GCA mean squares. Thus, indicated the presence of non additive type of gene action for grain yield/plant. Computation of variance components also exhibited the pronounced role of non additive gene action in controlling the inheritance of grain yield/plant (Table 2). The similar conclusion that indicated non additive effects were obtained by [8] [25]. These results differed from the findings of [23] who found additive gene action for grain yield/plant.

Four parents showed positive GCA effects of which the genotype, Chakwal-50 was the best general combiner for grain yield/plant with highest positive GCA effects of 1.23 followed by 9797 (0.94) and one parent (9802) manifested negative GCA effects of -0.98 (Table 3 ). Estimates of specific combining ability showed that the crosses, $9802 \times$ Chakwal-86 and $9797 \times 9802$ exhibited the high positive SCA effects ( 2.48 and 2.18 respectively). Hybrid, $9797 \times$ Chakwal- 86 was the poorest specific combiner having highest negative value $(-2.60)$ followed by $9797 \times 9801(-1.90)$ (Table 4). The high positive reciprocal effects were depicted by the crosses namely $9802 \times 9797$ (2.22), Chakwal-86 $\times 9797$ (2.13) and Chakwal-86 $\times$ Chakwal-50 (2.02). Four parents showed negative reciprocal effects of $-4.06,-1.81,-1.58$ and -0.43 (Chakwal-50 $\times 9797$, Chakwal- $86 \times 9802,9801 \times$ 9797 and $9802 \times 9801$ respectively) (Table 5).

\section{Conclusion}

Parent Chakwal-50 proved to be the best general combiner for plant height, spike length, No. of spikelets per spike, No. of grains per spike and grain yield per plant. 9802 was the best general combiner for 1000 grain weight. 9797 showed high GCA effects for fertile tillers per plant while for flag leaf area Chakwal-86 was the good general combiner. So, it is concluded that Chakwal-50 may be used in breeding programmes to develop high yielding wheat varieties. $9802 \times$ Chakwal-86 was the best specific combination for grain yield per plant and most of the yield related traits and this specific combination can be used in developing hybrid varieties.

\section{References}

[1] Poehlman, J.M. and Sleeper, D.A. (1995) Breeding Field Crops. 4th Edition. Inc. Westport Connecticut, Ani.

[2] Government of Pakistan (2016-2017) Pakistan Economic Survey. Finance Division, Economic Advisory Wing, Islamabad.

[3] Carver, B.F. (2009) Wheat Science and Trade. Wiley, Danvers, 569. https://doi.org/10.1002/9780813818832

[4] Griffing, B. (1956) Concept of General and Specific Combining Ability in Relation to Diallel Crossing Systems. Australian. Journal of Biological Sciences, 9, 463-493. https://doi.org/10.1071/BI9560463

[5] Bolboaca, S.D., Jantschi, L., Sestras, A.F. and Sestras, R.E. (2010) Statistics and Genetic Analysis of Quantitative Traits Using Griffing's Experimental Method IV: A 
Practical Guideline. Bulletin UASVM Horti, 67, 56-64.

[6] Rashid, M.A.R., Khan, A.S. and Iftikhar, R. (2012) Genetic Studies for Yield and Yield Related Parameters in Bread Wheat. Am-Euras. Journal of Agricultural and Environmental Sciences, 12, 1579-1583.

[7] Farooq, J., Habib, I., Saeed, A., Nawab, N.N., Khaliq, I. and Abbas, G. (2006) Combining Ability for Yield and Its Components in Bread Wheat (Triticum aestivum L.). Journal of Agriculture and Social Sciences, 2, 207-211.

[8] Kashif, M. and Khan, A.S. (2008) Combining Ability Studies for Some Yield Contributing Traits of Bread Wheat under Normal and late Sowing Conditions. Pakistan journal of Agricultural Sciences, 45, 44-49.

[9] Kashif, M. and Khaliq, I. (2003) Determination of General and Specific Combining Ability Effects in a Diallel Cross of Spring Wheat. Pakistan Journal of Biological Sciences, 6, 1616-1620. https://doi.org/10.3923/pjbs.2003.1616.1620

[10] Rehman, A.U., Khaliq, I., Khan, M.A. and Khushnood, R.I. (2002) Combining Ability Studies for Polygenic Characters in Aestivum Species. International Journal of Agriculture and Biology, 4, 171-174.

[11] Hassan, G., Mohammad, F., Afridi, S.S. and Khalil, I. (2007) Combining Ability in the $\mathrm{F}_{1}$ Generations of Diallel Cross for Yield and Yield Components in Wheat. Sarhad Journal of Agriculture, 23, 937-942.

[12] Padhar, P.R., Madaria, R.B., Vachhani, J.H. and Dobariya, K.L. (2010) Combining Ability Analysis of Grain Yield and its Contributing Characters in Bread Wheat ( Triticum aestivum L. em. Thell) Under Late Sown Condition. International Journal of Agriculture Sciences, 6, 267-272.

[13] Rahim, M.A., Saleem, A., Salam, A., Shakeel, A., and Abbas, G. (2006) Combining Ability for Flag Leaf Area, Yield and Yield Components in Bread Wheat. Journal of Agriculture Research, 44, 175-180.

[14] Nazir, S., Khan, A.S. and Ali, Z. (2005) Combining Ability Analysis for Yield and Yield Contributing Traits in Bread Wheat. Journal of Agriculture and Social Sciences, 1, 129-132.

[15] Mahpara, S., Ali, Z. and Ahsan, M. (2008) Combining Ability Analysis for Yield and Yield Related Traits among Wheat Varieties and Their $\mathrm{F}_{1}$ Hybrids. International Journal of Agriculture and Biology, 10,599-604.

[16] Chowdhry, M.A., Rabbani, G., Subhani, G.M. and Khaliq, I. (1999) Combining Ability Studies for Some Polygenic Traits in aestivum spp. Pakistan Journal of Biological Sciences, 2, 434-437. https://doi.org/10.3923/pjbs.1999.434.437

[17] Khan, N., Bajwa, M.A. and Asi, A.G. (1985) Combining Ability Study in a Diallel Cross of Five Wheat Varieties. Pakistan Journal Agriculture Research, 6, 48-51.

[18] Parwar, K.K., Yadav, S.K., Baghel, K.S. and Singh, A.K. (2014) Study of Diallel Analysis in Bread Wheat for Yield and Its Components. International Journal of Science and Research, 3, 63-67.

[19] Sattar, A., Chaudhry, M.H., Shah, K.N. and Khan, S.B. (1992) Combining Ability Estimates in Five Wheat Varieties. Pakistan Journal Agriculture Research, 13, 301-305.

[20] Larik, A.S., Mahar, A.R., Kakar, A.A. and Shafkh, M.A. (1999) Heterosis, Inbreeding Depression and Combining Ability in Triticum aestivum L. Pakistan Journal of Agricultural Sciences, 36, 40-44.

[21] Ajmal, S., Asif, M. and Munir, M. (2004) Implication of Combining Ability: Analysis of Some Characteristics of Spring Wheat. Quarterly Science Vision, 9, 1-5. 
[22] Kalhoro, F.A., Rajpar, A.A., Kalhoro, S.A., Mahar, A., Ali, A., Otho, S.A., Soomro, R.N., Ali, F. and Baloch, Z.A. (2015) Heterosis and Combing Ability in $\mathrm{F}_{1}$ Population of Hexaploid Wheat (Triticum Aestivum L.). American Journal of Plant Sciences, 6, 1011-1026. https://doi.org/10.4236/ajps.2015.67107

[23] Masood, M.S. and Kronstad, W.E. (2000) Combining Ability Analysis over Various Generations in a Diallel Cross of Bread Wheat. Pakistan Journal Agriculture Research, 16, 1-4.

[24] Khan, M.A., Ahmad, N., Akbar, M., Rehman, A.U. and Iqbal, M.M. (2007) Combining Ability Analysis in Wheat. Pakistan Journal of Agricultural Sciences, 44, 1-5.

[25] Kamaluddin, Singh, R.M., Prasad, L.C., Abdin, M.Z. and Joshi, A.K. (2007) Combining Ability Analysis for Grain Filling Duration and Yield Traits in Spring Wheat (Triticum aestivum L. em. Thell.). Genetic and Molecular Biology, 30, 411-416. https://doi.org/10.1590/S1415-47572007000300018 